\title{
Social Capital Role on Pregnant Woman Health in Klaten, Central Java
}

\author{
Sri Panuntun'), Ravik Karsidi²), Bhisma Murti3), Muhammad Akhyar²) \\ 1)Doctoral Program in Health Promotion/ Community Development, \\ Universitas Sebelas Maret \\ 2)Faculty of Teaching and Educational Sciences, Universitas Sebelas Maret \\ 3)Masters Program in Public Health, Universitas Sebelas Maret
}

\begin{abstract}
Background: Maternal class, partnership with traditional birth attendant (TBA), and maternity waiting home are health community empowerment programs in North Klaten Subdistrict, Central Java, seem to be partial, even though they involve the same parties and the same goal to improve the health of pregnant women. The purpose of this study was to explore social capital role on pregnant woman health in Klaten, Central Java.

Subjects and Method: This was a qualitative study with a case study design in North Klaten Subdistrict, Klaten, Central Java. The data were collected by in-depth interview, observation, and document review.

Results: This study shows that in order for a pregnancy health program to run effectively it requires the integration of information on the health of pregnant women and the development of pregnancy can reduce the risk of late three, namely late decision making, late bringing to health facilities, and late getting health services that can affect maternal mortality. As an effort to provide the best service to pregnant women in maternal class, partnership with TBA, and maternity waiting home programs requires a network of cooperation (interconnection) between all parties involved through social capital in accordance with the agreement supported by the village government.

Conclusion: Maternal class, partnership with TBA, and maternity waiting home programs must run simultaneously to improve the health of pregnant women. social capital model is a model of collaboration between all parties involved in KBD, KIH and RTK through interconnection based on telephone and/or internet networks, so that information is exchanged about health conditions and the development of pregnancy.
\end{abstract}

Keywords: social capital, pregnant women, health, maternal class

\section{Correspondence:}

Sri Panuntun. Doctoral Program in Health Promotion/Community Development, Universitas Sebelas Maret, Jl. Ir. Sutami 36 A, Surakarta 57126, Central Java. Email: ichaku06@yahoo.com.

BACKGROUND
In 2017, Maternal Mortality Rate (MMR) in
Klaten Regency is still very high, which is
112.76 per 100,00o births, although 2015
and 2016 had dropped to 88.22 and 106.84
per 100,00o births (Klaten District Health
Office, 2018). The cause of the death of
pregnant women is because 4T (four too),
which is too much, too tight, too young and
too old. According to Diananto (2017),
there are $34 \%$ of the causes of death of

pregnant women because there are too many pregnant women (more than 3 children), whereas because pregnant women are too young and too old each ranges from $32.5 \%$ and because it is too tight at $1 \%$.

Various efforts have been made by the government as an effort to reduce the Maternal Mortality Rate. The next government effort to reduce MMR in North Klaten Subdistrict is through the midwife and traditional birth attendant (TBA) partnership program, maternal class, and mater- 
nity waiting home. The three programs for pregnancy health seem to run independently (partially) even though the parties involved are the same, such as pregnant women, midwives, traditional birth attendant, cadre, health center, integrated health post, and hospital, so that the implementation of pregnancy health programs becomes less effective.

Social capital is the relationships that are created and norms that shape the quality and quantity of social relations in society, namely as social glue that keeps community unity together. Social capital can be transmitted through cultural mechanisms, such as religion, culture, or historical habits (Fukuyama, 1999).

Network social capital is social capital that reaches different people in different situations, thus encouraging its members to use a lot of resources than is available in the community (Fauziah, 2014). According to Hasbullah (2006), social capital, especially networks and relations, is a potential that can synergize and uncover potential and other capital. The complexity of networks and relationships created in society is one indicator of community strength. According to Arjana (2010), social relations between individuals and groups in hierarchically different social strata are called social capital linking.

Pregnant women health programs that involve quite a number of parties should build a comprehensive network of collaboration. A party can carry out the same task even though in a different program, so it can save time, costs, and effort.

Based on the problems mentioned above, the purposes of the study are presented as follows.
1. To identify parties involved in the maternal class, partnership with TBA, and maternity waiting home programs in North Klaten District.

2. To analyze the role of the parties involved in the KBD, KIH and RTK programs in North Klaten District.

3. To formulate the social capital model and its role in the health of pregnant women in North Klaten Sub-district.

\section{SUBJECTS AND METHOD \\ 1. Study Design \\ This was a qualitative study conducted in North Klaten Sub-district, Klaten, Central Java, Indonesia.}

\section{Study Informants}

The key informants were head of Klaten district government, head of North Klaten sub-district government, North Klaten community health center, midwive, cadre, traditional birth attendant, pregnant women, and nursing mother.

\section{Data Analysis}

The data were collected by in-depth interviews, observation, and focus group discussion (FGD) with pregnant women, posyandu cadres, village midwives, and village governments. The data collection uses triangulation of data collection techniques, source source triangulation, and theory triangulation. Based on study objectives, data analysis was presented in Table 1.

Data collection, data analysis and conclusion were conducted using an interactive analysis model. According to Miles and Huberman (1992) and Sugiyono (2009), interactive models are data analysis consisting of data reduction, data presentation, and interactive conclusions, and interconnected during and after data collection, such as Figure 1. 
Table 1. Data analysis tool based on study objectives

\begin{tabular}{lll}
\hline No & Purposes & Analysis Tool \\
\hline 1. & To identify parties involved in the maternal class, & Qualitative descriptive analysis \\
partnership with TBA, and maternity waiting home & \\
programs & \\
2. To review the functions and roles of parties involved & Qualitative descriptive analysis \\
in the maternal class, partnership with TBA, and & \\
maternity waiting home programs. & \\
3. & To formulate a social capital linking model and its & Structural analysis of events \\
& role in the health of pregnant women.
\end{tabular}

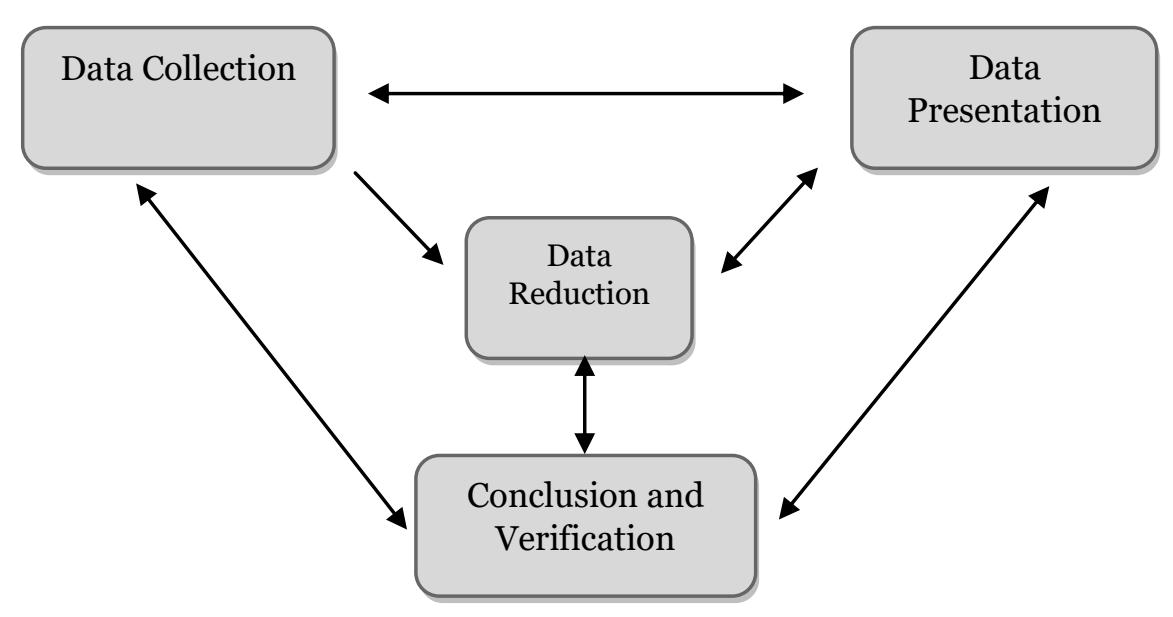

Figure 1. Interactive Model Data Analysis (Miles danHuberman, 1992)

\section{RESULTS \\ 1. Identification of parties involved in pregnant women health program}

The parties involved in maternal class, partnership with TBA, and maternity waiting home programs were based on the stages of the program which consisted of planning, implementing, monitoring and evaluating, and program sustainability as shown in Table 2.

Based on the data in Table 2, it can be seen that pregnant women, cadres, midwives, and traditional birth attendants as the center of activities for maternal class, partnership with TBA, and maternity waiting home programs were only involved in program implementation, even though the main principle of community empowerment was promoting community participation since planning, implementation, evaluation and program sustainability (Ife and Tesoriero, 2008).

\section{The role of the parties involved in pregnant women health program}

As shown in Table 2, there were nine parties involved in the maternal class, partnership with TBA, and maternity waiting home programs in North Klaten District, namely pregnant women, cadres, traditional birth attendants, village midwives, coordinating midwives, posyandu, health center, hospitals and district governments. The role of all parties involved in pregnancy health programs in North Klaten SubDistrict can be seen in Table 3 . 


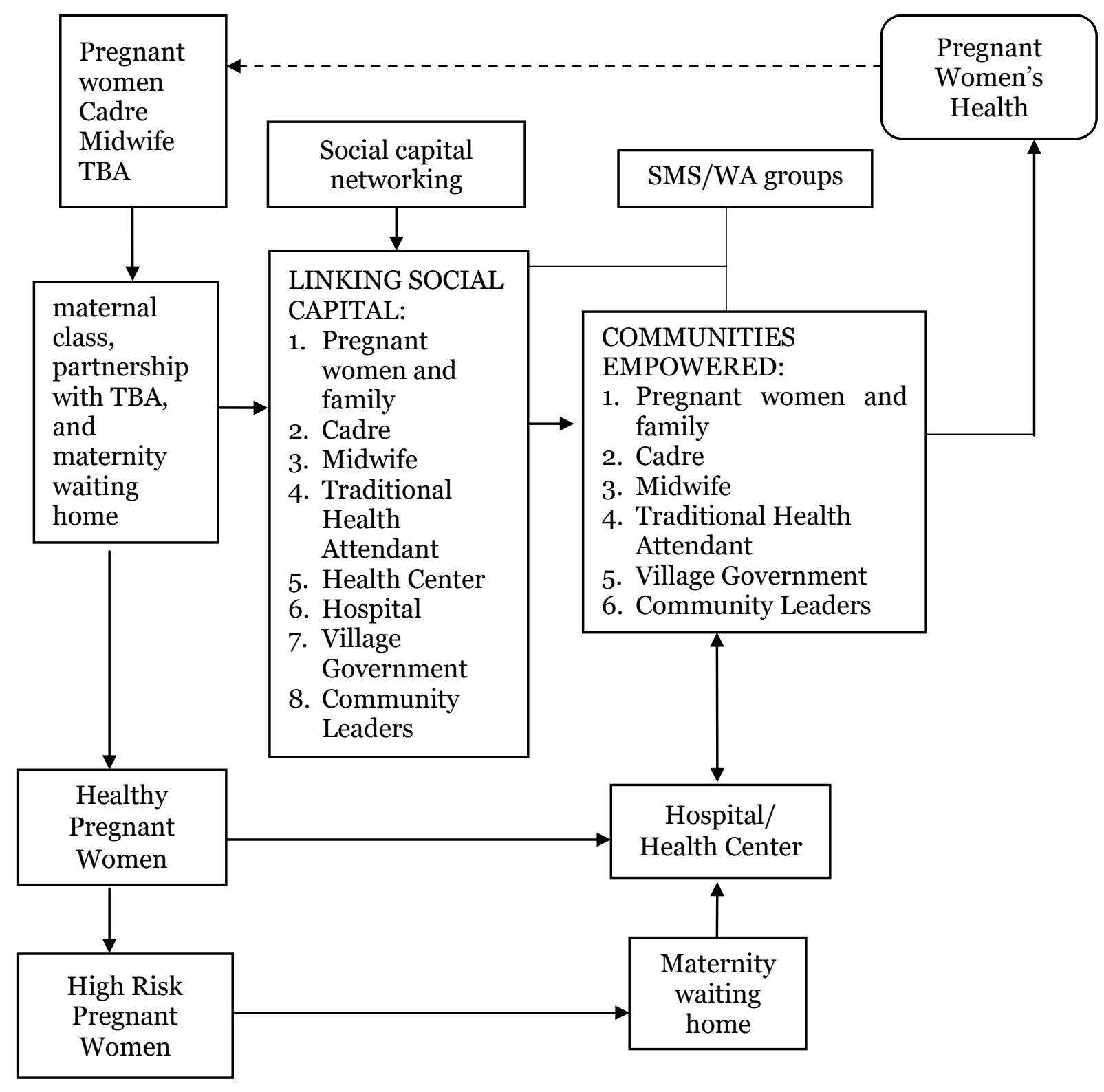

Figure 2. Linking social capital model for the health of pregnant women

Based on the role of all parties in the maternal class, partnership with TBA, and maternity waiting home programs as shown in the data in Table 3, all parties actually have the same roles in the KIH, KBD and RTK programs, therefore, the program was only one, and there was no need to have three program. The three programs were appropriate, but the three programs must be preceded by the KBD program supported by the KIH program, while pregnant women who were detected at high risk must go through the maternity waiting home before giving birth at the health center or hospital. 
Table 2. Parties involved in the maternal class, partnership with TBA, and maternity waiting home programs in North Klaten Sub-District

\begin{tabular}{|c|c|c|c|c|c|}
\hline \multirow{2}{*}{ No. } & \multirow{2}{*}{ Activities } & \multirow{2}{*}{ Parties Involved } & \multicolumn{3}{|c|}{ Programs } \\
\hline & & & KBD & KIH & RTK \\
\hline \multirow[t]{9}{*}{1} & \multirow[t]{9}{*}{ Planning } & Pregnant Women & $\mathrm{x}$ & $\mathrm{x}$ & $\mathrm{x}$ \\
\hline & & Cadre & $\mathrm{x}$ & $\mathrm{x}$ & $\mathrm{x}$ \\
\hline & & Traditional Healer & $\mathrm{x}$ & $\mathrm{x}$ & $\mathrm{x}$ \\
\hline & & Village midwife & $\mathrm{x}$ & $\mathrm{x}$ & $\mathrm{x}$ \\
\hline & & Coordinating Midwife & $\sqrt{ }$ & $\sqrt{ }$ & $\sqrt{ }$ \\
\hline & & Posyandu & $\mathrm{x}$ & $\mathrm{x}$ & $\mathrm{x}$ \\
\hline & & Health Center & $\sqrt{ }$ & $\sqrt{ }$ & $\sqrt{ }$ \\
\hline & & Hospital & $\sqrt{ }$ & $\sqrt{ }$ & $\sqrt{ }$ \\
\hline & & District government & $\sqrt{ }$ & $\sqrt{ }$ & $\sqrt{ }$ \\
\hline \multirow[t]{9}{*}{2} & \multirow[t]{9}{*}{ Implementation } & Pregnant Women & $\sqrt{ }$ & $\sqrt{ }$ & $\sqrt{ }$ \\
\hline & & Cadre & $\sqrt{ }$ & $\sqrt{ }$ & $\sqrt{ }$ \\
\hline & & Traditional Healer & $\sqrt{ }$ & $\sqrt{ }$ & $\sqrt{ }$ \\
\hline & & Village midwife & $\sqrt{ }$ & $\sqrt{ }$ & $\sqrt{ }$ \\
\hline & & Coordinating Midwife & $\sqrt{ }$ & $\sqrt{ }$ & $\sqrt{ }$ \\
\hline & & Posyandu & $\sqrt{ }$ & $\sqrt{ }$ & $\sqrt{ }$ \\
\hline & & Health Center & $\sqrt{ }$ & $\sqrt{ }$ & $\sqrt{ }$ \\
\hline & & Hospital & $\sqrt{ }$ & $\sqrt{ }$ & $\sqrt{ }$ \\
\hline & & District government & $\sqrt{ }$ & $\sqrt{ }$ & $\sqrt{ }$ \\
\hline \multirow[t]{9}{*}{3} & \multirow{9}{*}{$\begin{array}{l}\text { Monitoring and } \\
\text { evaluation }\end{array}$} & Pregnant Women & $\mathrm{x}$ & $\mathrm{x}$ & $\mathrm{x}$ \\
\hline & & Cadre & $\mathrm{x}$ & $\mathrm{x}$ & $\mathrm{x}$ \\
\hline & & Traditional Healer & $\mathrm{x}$ & $\mathrm{x}$ & $\mathrm{x}$ \\
\hline & & Village midwife & $\mathrm{x}$ & $\mathrm{x}$ & $\mathrm{x}$ \\
\hline & & Coordinating Midwife & $\sqrt{ }$ & $\sqrt{ }$ & $\sqrt{ }$ \\
\hline & & Posyandu & $\mathrm{x}$ & $\mathrm{x}$ & $\mathrm{x}$ \\
\hline & & Health Center & $\sqrt{ }$ & $\sqrt{ }$ & $\sqrt{ }$ \\
\hline & & Hospital & $\mathrm{x}$ & $\mathrm{x}$ & $\mathrm{x}$ \\
\hline & & District government & $\sqrt{ }$ & $\sqrt{ }$ & $\sqrt{ }$ \\
\hline \multirow[t]{9}{*}{4} & \multirow[t]{9}{*}{ Program sustainability } & Pregnant Women & $\mathrm{x}$ & $\mathrm{x}$ & $\mathrm{x}$ \\
\hline & & Cadre & $\mathrm{x}$ & $\mathrm{x}$ & $\mathrm{x}$ \\
\hline & & Traditional Healer & $\mathrm{x}$ & $\mathrm{x}$ & $\mathrm{x}$ \\
\hline & & Village midwife & $\mathrm{x}$ & $\mathrm{x}$ & $\mathrm{x}$ \\
\hline & & Coordinating Midwife & $\sqrt{ }$ & $\sqrt{ }$ & $\sqrt{ }$ \\
\hline & & Posyandu & $\mathrm{x}$ & $\mathrm{x}$ & $\mathrm{x}$ \\
\hline & & Health Center & $\sqrt{ }$ & $\sqrt{ }$ & $\sqrt{ }$ \\
\hline & & Hospital & $\sqrt{ }$ & $\sqrt{ }$ & $\sqrt{ }$ \\
\hline & & District government & $\sqrt{ }$ & $\sqrt{ }$ & $\sqrt{ }$ \\
\hline
\end{tabular}

Source: Primary Data Processed (2018)

Description: $\sqrt{ }=$ involved, $\mathrm{x}=$ uninvolved 
Journal of Health Policy and Management (2019): 4(1): 59-66

https://doi.org/10.26911/thejhpm.2019.04.01.07

Table 3. The role of the parties involved in maternal class, partnership with TBA, and maternity waiting home programs in Norh Klaten Sub-District

No. Parties Involved The Role in maternal class, partnership with TBA, and
maternity waiting home programs

\begin{tabular}{|c|c|c|}
\hline 1 & Pregnant Women & $\begin{array}{l}\text { a) Maternal class, partnership with TBA, and maternity waiting } \\
\text { home programs beneficiaries } \\
\text { b) Participate in the maternal class, partnership with TBA, and } \\
\text { maternity waiting home programs } \\
\text { c) Carry out and implement the obligations in the maternal class, } \\
\text { partnership with TBA, and maternity waiting home programs }\end{array}$ \\
\hline 2 & Cadre & $\begin{array}{l}\text { a) Assisting the duties of village midwives in relation to the } \\
\text { community. } \\
\text { b) Being a mediator between village midwives and pregnant } \\
\text { women. } \\
\text { c) Following the instructions set out in the maternal class, } \\
\text { partnership with TBA, and maternity waiting home programs. }\end{array}$ \\
\hline 3 & $\begin{array}{l}\text { Traditional Birth } \\
\text { Attendants }\end{array}$ & $\begin{array}{l}\text { a) Helping village midwives to observe and provide counseling to } \\
\text { pregnant women. } \\
\text { b) Carrying out duties as stipulated in the guidelines for } \\
\text { implementing the health personnel and TBA partnership } \\
\text { program. } \\
\text { c) Carrying out baby and postpartum mother massage. }\end{array}$ \\
\hline 4 & Village Midwife & $\begin{array}{l}\text { a) As a coach for the area in the village. } \\
\text { b) Being a speaker at the maternal class. } \\
\text { c) Provide instructions and direction on the duties of cadres and } \\
\text { traditional birth attendants. } \\
\text { d) Reporting the activities of maternal class, partnership with } \\
\text { TBA, and maternity waiting home programs in the village to } \\
\text { the health center through the midwife coordinator. }\end{array}$ \\
\hline 5 & Coordinating Midwife & $\begin{array}{l}\text { a) Coordinating the implementation of the duties of midwives } \\
\text { throughout the sub-district. } \\
\text { b) Receiving the reports on the implementation of village midwife } \\
\text { duties. } \\
\text { c) Connecting the health center to the midwives in the village. }\end{array}$ \\
\hline 6 & Posyandu & $\begin{array}{l}\text { a) Maternal class, partnership with TBA, and maternity waiting } \\
\text { home unit in the village. } \\
\text { b) Center for associations of parties involved in the maternal } \\
\text { class, partnership with TBA, and maternity waiting home } \\
\text { programs. }\end{array}$ \\
\hline 7 & Health Center & $\begin{array}{l}\text { a) Centers for pregnancy health referrals from village midwives. } \\
\text { b) Making pregnancy health referrals to hospitals. }\end{array}$ \\
\hline 8 & Hospital & Ultimate handling of pregnancy health center. \\
\hline 9 & District government & $\begin{array}{l}\text { Regulators, planning and supervision of the maternal class, } \\
\text { partnership with TBA, and maternity waiting home programs }\end{array}$ \\
\hline
\end{tabular}

\section{DISCUSSION}

Social capital model for the health of pregnant women

The effectiveness of the implementation of community empowerment programs for the health of pregnant women consisting of maternal class, partnership with TBA, and maternity waiting home programs can occur through the support of Linking Social Capital. Linking Social Capital was the central point of relations between all parties involved in the maternal class, partnership with TBA, and maternity waiting home pro- 
grams, so that they can run in the same direction in improving the health of pregnant women. Linking Social Capital acts as a medium between pregnant women, cadre, TBA, village midwives and the community who care for pregnant women around them.

The role of Linking Social Capital on the health of pregnant women can be implemented through:

1. There is a social agreement about the importance of caring for the health of pregnant women.

2. Pregnant women who reported and were known by cadres, village midwives and traditional birth attendants would become participants in maternal class and midwife and TBA partnerships.

3. Pregnancy health programs consisting of maternal class, partnership with TBA, and maternity waiting home involved various parties, namely pregnant women and their families, cadres, traditional birth attendants, village governments and community leaders.

4. Pregnant women and all parties involved who care about the health of pregnant women were in a communication network that provide information to each other about the development of pregnancy.

5. A communication network between pregnant women and all parties concerned about pregnant women can be made based on social media such as Short Message Services (SMS) and WhatsApp Groups (WA).

6. If pregnant women were in an emergency, the community can provide referrals directly to the nearest health center or hospital.

Based the results of this study it can conclude that:

1. Parties involved in maternal class, partnership with TBA, and maternity waiting home programs in North Klaten Subdistrict were pregnant women, cadre, TBA, midwives, health center, hospital, and the Klaten Regency Government.

2. All parties have the same roles in the maternal class, partnership with TBA, and maternity waiting home programs, so that there was only one program instead of three programs. maternal class, partnership with TBA, and maternity waiting home programs must run simultaneously to improve the health of pregnant women. The three programs must be preceded by the midwife and TBA partnership program supported by the maternal class program, while the pregnant women who were detected at high risk must go through the maternity waiting home before giving birth at the health center or hospital.

3. Linking Social Capital Model was a model of collaboration between all parties involved in the maternal class, partnership with TBA, and maternity waiting home programs through telephone and/or internet network-based interconnection, therefore, there was exchanges information about health conditions and the development of pregnancy so that there was no "three late" treatment to pregnant women to childbirth and postpartum, which was late decision making, late in going to health facilities, and late in getting health services.

\section{REFERENCES}

Arjana IGB (2010). Geografi dalam Ilmu Pengetahuan Sosial untuk Mengembangkan Modal Sosial. Jurnal Pendidikan dan Pengajaran. 43(3): 192 198.

Diananto N (2017). Faktor Penyebab Utama Kematian Ibu Hamil di Kabupaten 
Journal of Health Policy and Management (2019): 4(1): 59-66

https://doi.org/10.26911/thejhpm.2019.04.01.07

Majalengka. Jurnal Kesehatan Masyarakat. 8(24): $276-284$.

Dinas Kesehatan Kabupaten Klaten (2018). Profil Dinas Kesehatan Kabupaten Klaten Tahun 2017.

Fauziah N (2014). Peran modal sosial dalam kesejahteraan ekonomi rumah tangga petani. Institut Pertanian Bogor. Bogor.

Fukuyama F (1999). Social Capital in Civil Society. The Institute of Public Policy, George Mason University.
Hasbullah J (2006). Social Capital (Menuju Keunggulan Budaya Manusia Indonesia).MR-United Press. Jakarta.

Ife J, Tesoriero F (2008). Community Development. Alternatif Pengembangan Masyarakat di Era Globalisasi. Edisi Ketiga. Pustaka Pelajar. Yogyakarta.

Miles MB, Huberman AM (1992). Analisis Data Kualitatif. Universitas Indonesia Press. Jakarta.

Sugiyono (2009). Metode Penelitian Kuantitatif dan Kualitatif. Cetakan ke 6 . Penerbit Alfabeta, Bandung. 